\title{
PELAKSANAAN METODE SAS DALAM KEGIATAN BELAJAR MENGAJAR MEMBACA DAN MENULIS PERMULAAN DI KELAS 2 SDN 2 LOLU
}

\author{
Dedi Siswanto \\ Program Studi Pendidikan Bahasa dan Sastra Indonesia, FKIP, Universitas Alkhairaat \\ dedisiswanto@gmail.com
}

\begin{abstract}
ABSTRAK
Penelitian ini bertujuan untuk mendeskripsikan pelaksanaan Metode SAS dalam kegiatan Belajar Mengajar Membaca dan Menulis Permulaan di Kelas 2 SDN 2 Lolu. Peranan guru sebagai manajer dalam kegiatan belajar di kelas sudah lama diakui sebagai salah satu faktor yang penting dalam meningkatkan prestasi belajar siswa. Guru sebagai tenaga profesional, dituntut tidak hanya mampu mengelola kelas, yaitu menciptakan dan mempertahankan kondisi itu sejalan dengan upaya pemerintah dalam meningkatkan mutu di semua jenjang pendidikan, penerapan strategi pengelolaan kelas dalam pembelajaran merupakan salah satu altenatif yang diyakini dapat digunakan untuk memecahkan persoalan yang mendasar dari permasalahan di tanah air.
\end{abstract}

Kata Kunci : SAS, Membaca, Menulis

\begin{abstract}
This study aims to describe the implementation of the SAS Method in Teaching and Reading Activities Beginning and Writing in Class 2 SDN 2 Lolu. The role of the teacher as a manager in learning activities in the classroom has long been recognized as one of the important factors in increasing student achievement. Teachers as professionals are required not only to be able to manage classrooms, namely creating and maintaining conditions in line with government efforts to improve quality at all levels of education, the application of classroom management strategies in learning is one alternative that is believed to be used to solve the fundamental problems of problems in the country.
\end{abstract}

Keywords : SAS, Reading, Writing

\section{PENDAHULUAN}

Ketepatan pemilihan metode pembelajaran tersebut berpengaruh terhadap keinginan dan minat peserta didik dalam mengikuti prosese KBM. Pelaksanaan proses KBM di kelas rendah sekolah dasar tentu berbeda penggunaan metode pembelajarannya dengan kelas tinggi. Apa bila guru menggunakan metode pembelajaran dalam proses KBM menarik serta dikuasai maka dengan sendirinya peserta didik tertarik dan merasa beta di kelas.Sebaliknya apa bila guru menggunakan metode tidak dikuasai dan tidak menarik akibatnya peserta didik jenuh dalam menerima materi pelajaran.

Soedijarto (dalam Sukidin, dkk, 2008) menyatakan guru professional ialah guru yang memiliki kemampuan professional, yaitu mampu untuk dapat: (merencanakan program belajar mengajar,(2) melaksanakan kegiatan belajar mengajar,(3) menilai kemajuan kegiatan belajar mengajar, dan (4) menafsirkan dan memanfaatkan hasil penilaian kemajuan kegiatan belajar 
mengajar untuk penyempurnaan perencanaan kegiatan belajar mengajar.Sebagai seorang guru professional guru harus mampu melaksanankan hal itu dalam kegiatan belajar mengajar di dalam kelas untuk setiap mata pelajaran.Salah satu mata pelajaran yang dimaksud tersebut adalah mata pelajaran bahasa Indonesia.Untuk mata pelajaran bahasa Indonesia mulai dari jenjang pendidikan dasar, menengah, dan perguruan tinggi terdapat empat aspek keterampilan berbahasa yang perlu dipelajari dan dikuasai oleh peserta didik yaitu: (1) keterampilan menyimak,(2) keterampilan berbicara, (3) keterampilan membaca, dan (4) keterampilan menulis. Dari empat keterampilan berbahasa tersebut saling berhubungan satu dengan yang lain. Dua keterampilan berbahasa yang menjadi menjadi perhatian peneliti, yaitu: (1) keterampilan membaca dan (2) keterampilan menulis.

Sehubungan dengan kedua jenis keterampilan berbahasa tersebut, yaitu membaca dan menulis merupakan aktivitas berbahasa ragam tulis.Menulis adalah kegiatan berbahasa yang bersifat produktif, sedangkan membaca merupakan kegiatan berbahasa yang bersifat reseptif. Sementara menulis untuk menyampaikan ide,gagasan,pesan, atau informasi dalam bentuk tulisan.Sebaliknya,siswa membaca guna memahami ide,gagasan,perasaan, atau informasi yang disajikan dalam bentuk tertulis. Oleh karena itu, kedua jenis keterampilan berbahasa ini merupakan materi pembelajaran bahasa Indonesia yang utama bagi siswa kelas 2 atau kelas rendah. Hal ini disebabkan karena siswa kelas 2 SDN 2 Lolu masih banyak yang belum lancer membaca dan menulis.Berdasarkan fakta dilapangan tersebut,fenomena ini nmenarik untuk dijadikan focus penelitian.

\section{METODE PENELITIAN}

Dalam penelitian ini peneliti melakukan penelitian tindakan kelas.
Penelitian ini terdiri dari dua siklus yang terdiri dari empat tahap. Secara garis besar dapat di lihat pada gambar yang mengacu pada model yang dikemukakan oleh Kemmis dan Taggart (Wardhani, 2007).

Prosedur penelitian tindakan kelas ini terdiri dari dua siklus, tiap siklus dilaksanakan sesuai dengan perubahan yang ingin dicapai. Untuk dapat meningkatkan kemampuan siswa dalam membaca dan menulis maka diberikan tes awal yang berfungsi sebagai evaluasi tahap awal. Tes awal dilakukan untuk mengukur kemampuan siswa dalam membaca dan menulis kalimat sederhana. Hal ini diberikan dalam rangka memperbaiki cara membaca dan menulis permulaan yang baik dan benar kepada siswa.

Jenis data yang digunakan dalam penelitian tindakan kelas (PTK) adalah data verbal dan data non verbal. Data verbal ialah berupa tuturan siswa saat kegiatan belajar mengajar di kelas berupa kegiatan membaca dan menulis berlangsung. Sedangkan data non verbal ialah data berupa perolehan skor tes criteria ketuntasan minimal (KKM) yang telah ditetapkan dalam KTSP mata pelajaran bahasa Indonesia kelas dua SDN 2 Lolu.

Pengumpulan data pada penelitian ini dilakukan dengan beberapa cara antara lain tes hasil belajar siswa, dilakukan setelah kegiatan pembelajaran berakhir. Observasi dilakukan pada saat proses kegiatan pembelajaran sedang berlangsung yang meliputi observasi siswa dan guru melalui metode SAS.

\section{HASIL DAN PEMBAHASAN}

Hasil penelitian diambil pada saat
proses kegiatan belajar mengajar
berlangsung. Dari hasil tersebut, maka
diperoleh nilai observasi. Nilai hasil
observasi dalam kegiatan belajar mengajar
dapat dilihat pada tabel 1 berikut ini.


Tabel 1. Hasil Observasi Guru dalam Kegiatan Belajar Mengajar

\begin{tabular}{|c|c|c|c|c|}
\hline \multirow[b]{2}{*}{ No } & \multirow[b]{2}{*}{ Aspek yang dinilai } & \multicolumn{3}{|c|}{ Nilai } \\
\hline & & Baik & Cukup & Kurang \\
\hline 1 & Persiapan mental dan fisik siswa & $\sqrt{ }$ & & \\
\hline 2 & $\begin{array}{l}\text { Membimbing siswa mengenal topic } \\
\text { pembelajaran }\end{array}$ & $\sqrt{ }$ & & \\
\hline 3 & $\begin{array}{l}\text { Penguasaan metode gambar dalam } \\
\text { menulis cerita }\end{array}$ & $\sqrt{ }$ & & \\
\hline 4 & Pengelolaan kelas & $\sqrt{ }$ & & \\
\hline 5 & Pemanfaatan penggunaan waktu & $\sqrt{ }$ & & \\
\hline 6 & $\begin{array}{l}\text { Kesesuaian isi dan implementasi } \\
\text { tindakan yang ditetapkan. }\end{array}$ & $\sqrt{ }$ & & \\
\hline 7 & $\begin{array}{l}\text { Strategi dan implementasi tindakan } \\
\text { yang ditetapkan. }\end{array}$ & $\sqrt{ }$ & & \\
\hline 8 & $\begin{array}{l}\text { Kesesuaian gambar berseri yang } \\
\text { digunakan }\end{array}$ & $\sqrt{ }$ & & \\
\hline 9 & Penyimpulan materi & & $\sqrt{ }$ & \\
\hline 10 & $\begin{array}{l}\text { Kesesuaian alat penilaian dengan } \\
\text { indikator }\end{array}$ & & $\sqrt{ }$ & \\
\hline 11 & $\begin{array}{l}\text { Melaksanakan evaluasi akhir } \\
\text { pengajaran }\end{array}$ & & & $\sqrt{ }$ \\
\hline 12 & Menutup pelajaran & & & $\sqrt{ }$ \\
\hline
\end{tabular}

Berdasarkan tabel di atas dapat diperoleh gambaran tentang kemampuan guru (peneliti) dalam melaksanakan kegiatan proses pembelajaran pada siklus pertama di kelas II SDN 2 Lolu. Dari 12 aspek komponen yang diamati setiap 1 aspek skor nilainya $8,33 \%$. Dari hasil observasi aktivitas guru pada siklus I 1 nilai kurang 8,33\%, nilai cukuk 4 aspek komponen atau $33,32 \%$, dan nilai baik sebesar $58,31 \%$ atau 7 aspek komponen dari 12 aspek yang dinilai.Dengan melihat hasil perolehan nilai baik 58,33\% masih tinggi, maka guru (peneliti) perlu melakukan refleksi perbaikan pada siklus berikutnya. Hal ini disebabkan, karena keberhasilan dalam kegiata proses belajar mengajar ditentukan oleh kemampuan guru dalam memberikan materi pembelajaran.

Observasi terhadap aktivitas siswa dilakukan saat kegiatan belajar mengajar berlangsusng di kelas. Berdararkan hasil pengamatan pada siklus I, rata-rata siswa yang tidak aktif sebesar $30 \%$, sementara yang aktif $70 \%$, sehingga dengan melihat jumlah rata-rata siswa yang tidak aktif pada saat proses pembelajaran, maka dengan dengan demikian akan perlu diadakan perbaikan selanjutnya terutama bagi peningkatan motivasi dan partisipasi siswa yang tidak aktif.

Selanjutnya, Berdasarkan hasil tes membaca dan menulis, diperoleh bahwa jumlah rata-rata perolehan nilai siswa dalam kelas $59,81 \%$. Sedangkan ketuntasan hasil belajar siswa yang tidak tuntas sebanyak 10 orang siswa atau $62,5 \%$ dan siswa yang tuntas 6 orang atau 37,5\%. Maka dengan demikian hasil ini perlu dilakukan tindakan pada siklus selanjutnya.

Kegiatan pembelajaran dilanjutkan dengan pelaksanaan siklus II. Berdasarkan hasil penelitian, dapat di peroleh gambaran tentang kemampuan guru melakukan pembelajaran pada siklus II. Dapat dikatakan dari komponen yang yang diamati tidak ada nilai kurang, sementara nilai cukup berjumlah 2 aspek atau 18,66 sedangkan nilai baik berjumlah 10 orang atau $74,97 \%$. Dengan demikian melihat aspek komponen yang diamati telah ada peningkatan maka peneliti tidak perlu lagi mengulang untuk siklus berikutnya.

Berdasarkan hasil pengamatan yang dilakukan peneliti pada siklus II, ternyata jumlah rata-rata siswa yang aktif mengalami peningkatan yang signifikan. Hal ini disebabkan, karena siswa sudah aktif dan 
termotivasi dalam mengikuti proses pembelajaran. Siswa yang aktif pada siklus II $90 \%$ sedangkan yang tidak aktif $10 \%$.Dengan demikian terbukti bahwa melalui metode SAS dapat membuat siswa lebih antusias dalam mengikuti proses belajara mengajar membaca dan menulis.

Selanjutnya, berdasarkan hasil tes membaca dan menulis permulaan di atas dapat dilihat bahwa jumlah rata-rata kelas $77,25 \%$. Sedangkan ketuntasan hasil belajar siswa yang tuntas sebanyak 15 orang siswa atau $93,75 \%$ dan siswa yang tuntas 1 orang siswa atau $6,25 \%$. Maka dengan demikian hasil ini perlu dilakukan tindakan pada siklus selanjutnya.

Berdasarkan hasil analisa data sebagai hasil penelitian peningkatan hasil belajar kemampuan membaca dan menulis permulaan serta peningkatan aktivitas siswa terhadap metode SAS diperoleh gambaran sebagai berikut:

1. Hasil belajar menulis cerita dengan gambar berseri pada pembelajaran bahasa Indonesia. Hasil belajar diperoleh dari hasil tes unjuk kerja kemampuan membaca dan menulis permulaan yang dilakukan pada akhir setiap siklus.

2. Mencermati hasil pencapaian di atas menunjukan bahwa hasil belajar kemampuan menulis cerita dengan gambar berseri dari siklus I ke siklus II mkemperlihatkan adanya peningkatan yang siknivikan berarti dari rata-rata hasil belajar siklus I sebesar 59,81 naik menjadi $77,25 \%$ pada siklus II atau naik sebesar $17,44 \%$. Dengan melihat hal tersebut, ketuntasan hasil belajar secara klasikal dari $37,5 \%$ pada siklus I meningkat menjadi $93,75 \%$ pada siklus II atau mengalami peningkatan sebesar $56,25 \%$. Hasil yang diperoleh tersebut telah memenuhi kriteria ketuntasan belajar secara klasikal sebagaimana yang ditetapkan pada indikator penelitian ini sebesar $75 \%$.

3. Hasil keaktifan siswa dalam pembelajaran membaca dan menulis permulaan dengan metode SAS . Keaktifan dan respon siswa melalui pengamatan selama melakukan akifitas membaca dan menulis permulaan kelas menggunakan cek list dilakukan dalam proses pembelajaran jika siswa berada /sedang dalam keadaan tidak aktif dan aktif. Siswa yang dianggap tidak aktif jika siswa tersebut melakukan kegiatan yang tidak berhubungan dengan pembelajaran.

\section{KESIMPULAN}

1. Aktifitas siswa kelas II SDN 2 Lolu dalam membaca dan menulis permulaan secara efektif mengalami peningkatan yang cukup siknifikan. Peningkatan hasil belajar tersebut dilihat pada perolehan ketuntasan hasil belajar pada siklus II mengalami peningkatan sebesar $93,75 \% \%$, sedangkan ketuntasan hasil belajar pada siklus I secara sebesar $78,33 \%$ atau mengalami peningkatan sebesar 56,25\% dari siklus I

2. Aktivitas siswa selama pembelajaran tampak lebih efektif sejak siklus I hingga siklus II. Hasil perolehan menunjukan bahwa terjadinya peningkatan rata-rata keaktifan siswa dalam proses pembelajaran sebesar $61,66 \%$, dimana pada siklus I keaktifan siswa sebesar $70,00 \%$, sedangkan pada siklus II sebesar $90.00 \%$. Dengan demikian hipotesis yang menyatakan bahwa hasil kemampuan membaca dan menulis permulaan mengalami peningkatan melalui metode SAS pada kelas 2 SDN 2 Lolu.

\section{DAFTAR PUSTAKA}

Budiasih, Zuchdi, Darmiati. (1997). Pendidikan Bahasa Indonesia Di Kelas Rendah.Derparteman Pendidikan dan Kebudayaan Direktorat Jenderal Pendidikan Tinggi. Jakarta: Depdikbud.

Byrne, D. (1979). Teaching Writing Skills. England: Longman Group Ltd.

Depdiknas. (2009). Kurikulum Tingkat Satuan Pendidikan. Jakarta: Depdiknas.

Ewald, R, H. (1983). Writing as Proses Inventional and Convention. Colombus: A Bell \&Howell Company. 


\section{Pelaksanaan Metode SAS}

Goodman,K. (1988). The Reading Proses.Dalam Carel, P: Devine, J.\& Eskey, C. (eds). Interaktive approaches to Second Language Reading. Cambringdge: Cabridge University Press.

Momo. (1979). Penggunaan Metode SAS dalam Pengajaran Membaca di Sekolah Dasar. Jakarta : Departeman P dan K.

Sukidin. (2008). Manajemen Penelitian Tindakan Kelas. Jakarta : Insan Cendekia.

Suyanto (1997). Pedoman Pelaksanaan Penelitian Tindakan Kelas, Bagian kesatu Pengenalan Tindakan Kelas. Jakarta : Dirjen Dikti, Depdikbud.

Tampubolon. (1991). Mengembangkan minat dan Kebiasaan Membaca pada Anak. Bandung : Angkasa.

Tarigan, H.G. (1983). Menulis Suatu Keterampilan Berbahasa. Bandung: Angkasa.

Usman H.B. dkk. (2005). Pedoman Penyusunan dan Penilaian Karya Ilmiah. Palu: Untad. 